\title{
Researches on the Use of Micronized Product D.Z.D. (1: 1: 1) in Laboratory and Deposit Conditions for the Deacidification Treatments of the Info-Documentary Collections from Libraries, Archives and Museums
}

\author{
Vasile Deac \\ Researcher, PhD \\ "Gh. Sincai" County Library of Bihor, Oradea \\ E-mail Vasile_deac@yahoo.com \\ Ionela Burz \\ Librarian, $\mathrm{PhDc}$ \\ University of Oradea Library \\ E-mail ionela_burz@yahoo.com \\ Alexandru Deac \\ Specialist in systems engineering and environmental biotech \\ Inteva Company Ltd., Oradea \\ E-mail deac.alex38@yahoo.com
}

\begin{abstract}
For the protectionists (conservators, restorers) of the info-documentary collections in libraries (museums and archives), but also for the specialists who are studying techniques for the hygiene of cultural environments, natural nanoparticles represent untapped professional choices, which can have spectacular implications for the protection of info-cultural assets from Romanian libraries, museums and archives.

The paper represents a practical application developed and applied in library environments in order to establish the technology for the use of natural nanoparticles to protect the infocultural goods and to maintain the hygiene in the library environments .
\end{abstract}

Keywords: library collections; preservation; protection; nanoparticles; nanotechnologies; zeolite; diatomite

\section{General aspects}

Researches on the use of DZD [1] micronized product in laboratory and deposit conditions, for the deacidification treatments of the info-documentary collections in libraries, museums and archives, represent a scientific approach based on a research-development partnership program between the conservation-research laboratory within "Gheorghe Şincai" County Library, Oradea - represented by Dr. Vasile A. Deac, Scientific Researcher and SC Zeolitos SRL Oradea, represented by Florin Clepe, CEO of the institution.

The research entitled Studies on the influence of DZD nanoparticle treatments upon some chemical properties of the paper - practical applications on the library collections started in 2015 and will continue until the end of 2021, when we are going to have certain results on: the elaboration, testing and homologation of the nanoparticle-based products for the use in the chemical treatments of information-carrier papers from libraries, museums and archives; elaboration and application of the acidification neutralization technology (museum, archive) in the case of library collections for all info-documentary collectors (individuals and legal entities). The applications regarding the mechanical properties of the treated paper (resistance to tearing due to handling and research, as well as aspects of $\mathrm{pH}$ restoration and text-fixing, as well as the effects in

Revista Română de Biblioteconomie şi Ştiința Informării = Romanian Journal of Library and Information Science ISSN 2559-5490, ISSN-L 1841-1940 • Volume 14 Issue 12018 pp. 11-29 https://doi.org/10.26660/rrbsi.2018.14.1.11

This work is licensed under a Creative Commons Attribution-NonCommercial-NoDerivatives 4.0 International License 
Researches on the Use of Micronized Product D.Z.D. (1: 1:1)

in Laboratory and Deposit Conditions for the Deacidification Treatments

of the Info-Documentary Collections from Libraries, Archives and Museums

preventing the fauna and flora specific to the degraded collections will remain professional research efforts to highlight the plasticity of the products under the form of nanoparticles at atomic level, obtained by mechanical synthesis.

The combined nanometric structures (DZDs) are not only very small (1-23 microns), but they also possess totally unique and unexpected properties compared to each product analyzed separately. These properties can be extremely useful in the treatments for the preservation of the infodocument collections in libraries, museums and archives. Based on this nanometric structure of the fine particles from the nano-products within this composite, it is believed that the chemical synthesis of DZD product may have the ability to build new complexes, complying with its significance at the atomic level, which can generate positive effects for beneficial interventions in preserving the information-carrier paper. Performing basic laboratory investigations in parallel with the practical applications from the deposit on the info-documentary collections represent, for the team involved, scientific approaches essential for shortening the time of conducting laboratory analyzes and testing the research variants under different repetitions in order to obtain preliminary results. This experimental technique is required as a mandatory step to go through, being part of a wide-range scientific approach by which the research variants that reach a higher stage of research (nanoparticle-like products and / or by-products) are selected and analyzed.

Importance of the research programme:

- access of beneficiaries to environmentally-friendly, handy and qualitative products that can successfully compete with expensive, costly and demanding chemotherapeutic methods;

- it is believed that the usage of DZD complex product will represent, through the researched directions, a viable solution for the preservation and hygiene of the info-documentary collections from the libraries, museums and archives, namely for the chemotherapy treatments of the paper (deacidification of documents, restoration of paper's mechanical and chemical indices, fixing of text and color images) and prevention of the fungal complex specific to biodegradable documents);

- the use of Dolomite-zeolite (D1:Z1) represents a viable and of a great perspective solution that can be used without restrictions in each library (museum or archive) for the performance of ecological chemotherapy treatments;

- diatomite with dolomite and zeolite, or separately, can represent a successful natural agent against pests in all the environments of a library, museum or archive; the death of the pests does not occur suddenly because the diatomite does not act chemically but mechanically, destroying the exoskeleton of the insects;

- the final stages of the research phases in this program will be punctuated by the activities of product homologation and the development of nanotechnologies for the involvement of the nanometric size products, approximately between 1 and $100 \mathrm{~nm}$ (one nanometer is a billionth or $10^{-9}$ part of a meter, one nanometer is as small when compared to an apple as an apple is when compared to the planet Earth);

- for the elaboration of nano-technologies, some nano-sized materials were used ranging from 3 to 63 microns [2];

- the researches started both in the Conservation-Research Laboratory within „Gheorghe Şincai” Bihor County Library, Oradea (fundamental laboratory research), but also in the collections of the deposits from the library in Oradea, as well as at „Gheorghe Asachi” Technical University from Iaşi, have laid the foundations of some new scientific concerns, which once started and deepened, will decipher aspects that will open up new strategies in laboratory techniques and the practice of using micronized products in applicative ecological chemotherapy from the library environments (collections and spaces);

- there are strong beliefs that this new field of research can develop viable, clean, non-toxic, effective, high-end solutions to save the written heritage from libraries, museums and archives. 
Researches on the Use of Micronized Product D.Z.D. (1: 1: 1)

in Laboratory and Deposit Conditions for the Deacidification Treatments

of the Info-Documentary Collections from Libraries, Archives and Museums

\section{Objectives, materials and research methods}

\subsection{Objectives}

The Conservation and Research Laboratory within "Gheorghe Şincai" County Library, Bihor, Oradea, conducts a sustained scientific activity on identifying new materials and developing conservation and restoration techniques that contribute to the protection and preservation of the cultural heritage of libraries, museums and archives. The reformation of the intervention system, as well as of the educational one in the field of Romanian cultural heritage protection, based on the scientific principles of investigation, evaluation and protection, represents a professional creed for the conservative specialists.

Currently, preservation as a stand-alone science uses technical instruments belonging to chemistry, physics, biology and microbiology, laboratory experimental techniques and, more recently, to nanotechnology. All these fields, with their own scientific structure and apparatus, strive to protect the cultural values of libraries, museums and archives through original and viable expertises and solutions.

Therefore, there are proposed, for analysis, the main objectives that are studied in the laboratory and in the practice of preserving the info-documentary collections from libraries, museums and archives:

- micronizing of materials compatible with the protection of the info-document collections from libraries, museums and archives;

- elaboration of intervention technologies in the preservation and restoration of info-document collections from libraries, museums and archives, compatible with the newly-identified and researched structures or networks;

- identification of zeolite-based natural products, presentation of the chemical composition silico-alumina component; laboratory tests on the use of zeolite products in the treatments regarding: decontamination and treatment of historical paper attacked by the fungicide complex specific to the paper; correction treatments of mechanical and chemical indices;

- micronization of the dolomite-based products, synthesis of hydroxy-alkali nanoparticles and their application on historical paper for the deacidification of library collections; fixing and preservation of texts and color images; restoration of paper structure and texture;

- development and application of the nanotechnology to prevent paper aging as long as possible by applying nanotechnology based on the technology that builds complex structures while complying with the atomic specifications by using mechanical synthesis;

- research on the properties of nanometric chemical structures in the chemo-paper treatments by microscopic study, compared to the properties of the same substance at macroscopic level;

- dynamics of the $\mathrm{pH}$ evolution for the library collections before and after treatment;

- laboratory and deposit research on the use of the diatomite product in the control of the creeping insects from library environments: deposits; modules for keeping and preserving infodocumentary collections from libraries, museums and archives; development of the technology for the use of diatomite product under the form of wet treatments (solutions under the form of emulsifiable concentrations in special cases) restrictions on the use of insect-fungicides in special deposits or other spaces with impact destinations for cultural institutions.

\subsection{Material and Research Method}

To justify the technology of using products under the form of Zeolite, Dolomite and Diatomite nanoparticles, some technical specifications were presented for each product that can be used in 
Researches on the Use of Micronized Product D.Z.D. (1: 1: 1)

in Laboratory and Deposit Conditions for the Deacidification Treatments

of the Info-Documentary Collections from Libraries, Archives and Museums

the conservation and restoration of the info-documentary collections, individually or in combinations.

\subsubsection{About Zeolite and the usage of the product in the conservation of the info-documentary collections}

Zeolites are considered as inorganic stoichiometric polymers whose properties are quantitatively correlated with the chemical composition. Because of silico-alumina compositions, $\mathrm{Al}^{3+}$ and $\mathrm{Si}^{4+}$ can be partly or totally replaceable with atoms of other elements and also because of the proven possibilities to crystallize in several structures (depending on the conditions of synthesis, the number of zeolite structures seems unlimited). Up to now, 41 natural zeolites have been identified and 430 zeolites and isotypes, that also contain 133 types of zeolite networks, have been obtained. The scientific interest in zeolitic and zeolite-type materials, including the protection of infodocuments in libraries, museums and archives, have spurred fundamental and applied research into the synthesis of new materials and new structures or networks. Thus, in 1970, 27 zeolite networks were known; in 1978 their number increased to 38; in 1988 their number increased to 64, in 1992 to 85 zeolite networks, in 1996 to 98 zeolite networks, and in 2001 there were recognized 133 zeolite networks.

Zeolite is a special mineral having a microcrystalline and dynamic structure with a strong detoxifying action, being the only mineral known to be negatively charged on the earth, offering the natural attraction and absorption capacity of positively charged pollutants. The zeolite is crystallized and functions as a chemical cocoon. Specialists also call it as the molecular sieve because it extracts the pollutant cations, bacteria, viruses. The essential role in the beneficial action of the Zeolite consists in its nanotubes, with the size of 4.5 Angstroms, which capture and retain heavy metal atoms, radioactive ions, viruses, microbes and infested molecules.

There are many varieties of zeolite used successfully in human medical practice, but a single variant of zeolite has very good capabilities in the protection of paper-based information papers, namely Clinoptilolite.

The zeolite variety offered by SC Zeolitos SRL and used in the tests performed in the conservation-research laboratory within „Gheorghe Şincai” Bihor County Library, Oradea, presents a mineralogical and chemical composition very useful for the treatments to filter, block, retain and then eliminate by washing a lot of contaminants specific to biodegraded collections. This special capacity belongs to the zeolite with Clinoptilolite variety: $71 \%-83.3 \%$. Table 1 highlights the technical specifications of the Zeolite product regarding the mineralogical and chemical composition, as well as other determinations, among which the most important are: $p H$ value; colour; cationic exchange capacity on calcium, magnesium, potassium, sodium ions; water absorption; total porosity.

In the treatments performed in the laboratory from Oradea on the preservation of the newsprint collections (Fáklya, years of appearance: 1979-1981, terms 1-4), the Zeolite product with its Clinoptilolite variety $83.3 \%$ represented the basic component together with Dolomite and Diatomite products, to form a complex solution (Zeolite + Dolomite $+2 \%$ Diatomite in distilled water with a $\mathrm{pH}=7$ ). For the preservation of the collections on low-quality paper (especially the newsprint), no other forms of zeolite are used, and more than this, no synthetic forms are used, for the sole reason that the synthetic zeolite is very expensive, being used only in certain special technological applications (special conservation and restoration). Zeolite micronization is the form in which the product is made accessible in the preservation treatments of the library collections. 
Researches on the Use of Micronized Product D.Z.D. (1: 1:1)

in Laboratory and Deposit Conditions for the Deacidification Treatments

of the Info-Documentary Collections from Libraries, Archives and Museums

Zeolite product with its Clinoptilolite variety $83.3 \%$ may be a safe option for the interventions on the preservation treatments of the info-documentary collections kept in insalubrious environments from libraries, museums or archives because:

- it filters, blocks, retains and then removes in the medium of the intervention solution a multitude of contaminants specific to biodegradable collections from the uncontrolled library, museum, or archive environments;

- in the researches carried out within the conservation-research laboratory of „Gheorghe Sincai” Bihor County Library, Oradea, the product behaved very well in a mixture with special nanoparticles for the insalubrious places contaminated with fungi, bacteria and viruses.

\begin{tabular}{|c|c|c|c|c|}
\hline \multirow{2}{*}{$\begin{array}{r}\begin{array}{r}\text { Crt. } \\
\text { no. }\end{array} \\
1 .\end{array}$} & \multicolumn{2}{|c|}{$\begin{array}{c}\text { Caracteristics/ } \\
\text { Material composition }\end{array}$} & \multirow{2}{*}{$\begin{array}{c}\text { Values } \\
71 \%-83.3 \%\end{array}$} & \multirow[t]{2}{*}{ Obs. } \\
\hline & Mineralogic composition & Clinoptilolite & & \\
\hline & & Vulcanized glass & $4.1 \%-9.7 \%$ & \\
\hline & & Plagioclase & $6.6 \%-6.67 \%$ & \\
\hline & & $\mathrm{SiO} 2$ & $2.25 \%-2.6 \%$ & \\
\hline & & Other minerals & $3.0 \%-4.0 \%$ & \\
\hline \multirow[t]{8}{*}{2.} & Chemical composition & $\mathrm{SiO} 2$ & $68.75 \%$ & \\
\hline & & $\mathrm{Al} 2 \mathrm{O} 3$ & $11.35 \%$ & \\
\hline & & $\mathrm{Si} \mathrm{O} 2 / \mathrm{A} 12 \mathrm{O} 3$ & $5 \%-7 \%$ & \\
\hline & & $\mathrm{Fe} 2 \mathrm{O} 3$ & $2.10 \%$ & \\
\hline & & $\mathrm{CaO}$ & $2.86 \%$ & \\
\hline & & $\mathrm{MgO}$ & $1.18 \%$ & \\
\hline & & $\mathrm{Na} 2 \mathrm{O}+\mathrm{K} 2 \mathrm{O}$ & $3.99 \%$ & \\
\hline & & P.C. & $9.77 \%$ & \\
\hline 3. & \multicolumn{2}{|c|}{ Apparent specific weight in dry state } & $1.650-1.75 \mathrm{gf} / \mathrm{cm}^{3}$ & \\
\hline 4. & \multicolumn{2}{|c|}{ Cationic exchange capacity (CEC) } & $1.6 \mathrm{mqv} / 100 \mathrm{~g}$ & \\
\hline 5. & \multicolumn{2}{|l|}{ Natural humidity } & $11-18 \%$ (according to season) & \\
\hline 6. & \multicolumn{2}{|c|}{ Specific surface (BET) } & $53.3 \mathrm{~m}^{2} / \mathrm{g}$ for 125 microns & \\
\hline 7. & \multicolumn{2}{|c|}{ Pore volume for the natural product } & $0.224 \mathrm{~cm}^{2} / \mathrm{g}$ & \\
\hline 8. & \multicolumn{2}{|l|}{ Pore diameter } & $3.82 \mathrm{~A}$ & \\
\hline 9. & \multicolumn{2}{|l|}{ Total porosity } & $33.08 \%$ & \\
\hline 10. & \multicolumn{2}{|l|}{ Water absorption } & $25 \%$ & \\
\hline 11. & \multicolumn{2}{|l|}{ Specific mass } & $2.15-2.25 \mathrm{~g} / \mathrm{cm}^{3}$ & \\
\hline 12. & \multicolumn{2}{|l|}{ Bulk density } & $0.88 \mathrm{~kg} / \mathrm{dm}^{3}$ & \\
\hline 13. & \multicolumn{2}{|l|}{$\mathrm{pH}$ value } & 9 & \\
\hline 14. & \multicolumn{2}{|l|}{ Colour } & White-gray & \\
\hline 15. & \multicolumn{2}{|c|}{ Smell } & No smell & \\
\hline 16. & \multicolumn{2}{|c|}{ Cationic exchange capacity on calcium ions } & $90-110 \mathrm{mqv} / 100 \mathrm{~g}$ & \\
\hline 17. & \multicolumn{2}{|c|}{ Cationic exchange capacity on magnesium ions } & $7-14 \mathrm{mqv} / 100 \mathrm{~g}$ & \\
\hline 18. & \multirow{2}{*}{\multicolumn{2}{|c|}{$\begin{array}{l}\text { Cationic exchange capacity on potassium ions } \\
\text { Cationic exchanoe canacity on sodium ions }\end{array}$}} & $44-54 \mathrm{mqv} / 100 \mathrm{~g}$ & \\
\hline 19. & & & $37 \mathrm{mqv} / 100 \mathrm{~g}$ & \\
\hline
\end{tabular}

Table 1. Zeolite - technical specifications 
Researches on the Use of Micronized Product D.Z.D. (1: 1:1)

in Laboratory and Deposit Conditions for the Deacidification Treatments

of the Info-Documentary Collections from Libraries, Archives and Museums

\subsubsection{Presentation of Dolomite product for the conservation treatments of info- documentary collections}

Micronized Dolomite (Calcium and Magnesium Carbonate) is a very important new technical way in which the product is processed to be accessible as a technology line for the conservation of the info-documentary collections. Promotion of dolomite as a sustainable technology for the intensive $\mathrm{pH}$-value correction treatments of valuable collections on paper is a constant direction of the research program within „Gheorghe Şincai” Bihor County Library, Oradea, to use nanometric products by using the mechanical synthesis, products that offer new structures useful in protecting the info-documentary collections.

The main effects of using dolomite in preserving old newsprint collections are:

- correcting the old paper with acid reaction ( $\mathrm{pH}$ between 4-5), at a neutral, slightly alkaline $\mathrm{pH}$ (7-8);

- beneficial effects on some chemical paper indices;

- fixing the text.

\begin{tabular}{|c|c|c|c|c|}
\hline $\begin{array}{l}\text { Crt. } \\
\text { no. }\end{array}$ & Elements & M.U. & Percent & Observations \\
\hline 1. & $\mathrm{Ca} \mathrm{CO} 3$ & $\%$ & 57.8048 & PH Optimum values \\
\hline 2. & $\mathrm{MgC} \mathrm{O} 3$ & $\%$ & 41.1103 & PH Optimum values \\
\hline 3. & $\mathrm{Al} 2 \mathrm{O} 3$ & $\%$ & 0.0357 & Subunitary value \\
\hline 4. & $\mathrm{SiO} 2$ & $\%$ & 0.1027 & Subunitary value \\
\hline 5. & $\mathrm{P} 2 \mathrm{O} 5$ & $\%$ & 0.0075 & Subunitary value \\
\hline 6. & $\mathrm{SO} 3$ & $\%$ & 0.0170 & Subunitary value \\
\hline 7. & $\mathrm{Cl}$ & $\%$ & 0.0044 & Subunitary value \\
\hline 8. & $\mathrm{~K} 2 \mathrm{O}$ & $\%$ & 0.0137 & Subunitary value \\
\hline 9. & $\mathrm{TiO} 2$ & $\%$ & 0.1029 & Subunitary value \\
\hline 10. & $\mathrm{~V} 2 \mathrm{O} 5$ & $\%$ & 0.0013 & Subunitary value \\
\hline 11. & $\mathrm{MnO}$ & $\%$ & 0.0572 & Subunitary value \\
\hline 12. & $\mathrm{Fe} 2 \mathrm{O} 3$ & $\%$ & 0.0760 & Subunitary value \\
\hline 13. & $\mathrm{CuO}$ & $\%$ & 0.0123 & Subunitary value \\
\hline 14. & $\mathrm{GeO} 2$ & $\%$ & 0.0131 & Subunitary value \\
\hline 15. & As2O3 & $\%$ & 0.0381 & Subunitary value \\
\hline 16. & $\mathrm{Se} \mathrm{O} 2$ & $\%$ & 0.0111 & Subunitary value \\
\hline 17. & $\mathrm{SrO}$ & $\%$ & 0.0262 & Subunitary value \\
\hline 18. & $\mathrm{BaO}$ & $\%$ & 0.2806 & Subunitary value \\
\hline 19. & Insoluble $\mathrm{HCl}$ & $\%$ & 1.0840 & \\
\hline
\end{tabular}

Table 2. Dolomite - composition

Concerning the composition of dolomite (see Table 2), the following aspects were highlighted:

- the variety of the studied dolomite contains a very high value of calcium carbonate (57.8048\%);

- magnesium carbonate is $41.1103 \%$;

- calcium and magnesium carbonate values are optimal in acid pH corrections treatments; 
Researches on the Use of Micronized Product D.Z.D. (1: 1: 1)

in Laboratory and Deposit Conditions for the Deacidification Treatments

of the Info-Documentary Collections from Libraries, Archives and Museums

- all the identified elements, except for calcium and magnesium carbonates, present insignificant subunit values as an impact on the $\mathrm{pH}$ neutralization processes.

Dolomite: technical specifications

Dolomite is a mineral from the anhydrous carbonate group, commonly found in nature. The mineral crystallizes in the trigonal-romboedric system, having the chemical formula $\mathrm{CaMg}(\mathrm{CO} 3) 2$, dominating the romboedric crystals or the massive gray-white aggregates with colour variants that can range up to light brown. It has a relatively low hardness, between 3.5 and 4 with a density of 2.9 .

\subsubsection{Presentation of Diatomite product and its use in the protection (preservation and restoration) of documents from libraries, museums and archives}

Diatomite is a siliceous sedimentary rock composed of stratiform rocks having a structure of 50\% diatomic/ diatomee residues entrapped in a white yellowish-to-brown opalescent mass, brittle and rough to the touch with homogeneous texture and high porosity. The rocks are lightweight with low density. The silicon oxide material is chemically neutral, dissolves in water and presents microscopic forms of incipient or advanced crystallization. The fact that diatomite is used, among other things, as a filler in the production of different types of paper, was a solid argument, besides other qualities, for its use in wet treatments for the preservation of info-documentary collections in libraries, archives and museums. Diatomite is a siliceous sedimentary rock formed mainly from the remnants of the diatomaceous shells. Diatomite is a whitish rock formed predominantly (over $50 \%)$ of diatomic frustules contained in an opal mass. It is a light rock, $(\mathrm{G}=0.4-0.9)$, friable and with high porosity $(90 \%)$. It is frequently stratified and associated with clays, micrites, or Miocene age tuffs. The material structure, from which it is formed, is the chemically neutral silicon oxide which does not dissolve in water.

Diatomaceous earth represents an insecticide with a natural effect, being considered a future insecticide with natural effects by the specialists. The insecticide-like action of the diatomite product is physico-mechanical and not through contact or ingestion as it occurs in the case of the insecticides of chemical nature, which end up by the contamination of soil, plants, animals and human beings.

Compared to the conventional chemical insecticides, diatomite as a natural insecticide does not induce resistance and immunity to insects, making permanent the intact insecticide capacity for a long period of time. Some specialists assert that the physico-mechanical action of diatomaceous earth is explained by a microscopic feature that produces a negative electron flow that permeates the body of the insects and the anatomical destabilization of the chitinated exoskeleton, producing death by dehydration and drying.

In the practice of diatomite use in the protection of various closed or open environments, the specialists have identified that the insecticidal power of diatomaceous earth is proved by having a small amount of pyrethrin, which irritates the nervous system of the insects. This feature of diatomite offers a technical possibility of using the product in various combinations to protect the collections from libraries, museums and archives, including the application of wet treatments.

Diatomite is effective in controlling insects in libraries such as: cockroaches, coleopters, mosquitoes, flies, fleas, ants, spiders. 
Researches on the Use of Micronized Product D.Z.D. (1: 1:1)

in Laboratory and Deposit Conditions for the Deacidification Treatments

of the Info-Documentary Collections from Libraries, Archives and Museums

\begin{tabular}{|c|c|c|c|c|}
\hline $\begin{array}{l}\text { Crt. } \\
\text { no. }\end{array}$ & Name - characteristic & M.U. & $\begin{array}{c}\text { Achieved aver- } \\
\text { age values }\end{array}$ & $\begin{array}{c}\text { Method of deter- } \\
\text { mination }\end{array}$ \\
\hline 1. & Loss when calcination, PC & $\%$ & 11.89 & \multirow{9}{*}{ STAS 1427-66 } \\
\hline 2. & Sulphur dioxide, Si02 & $\%$ & 68.25 & \\
\hline 3. & Aluminium trioxide, $\mathrm{Al} 2 \mathrm{O} 3$ & $\%$ & 11.17 & \\
\hline 4. & Iron trioxide, $\mathrm{Fe} 2 \mathrm{O} 3$ & $\%$ & 3.3 & \\
\hline 5. & Calcium oxide $\mathrm{CaO}$ & $\%$ & 2.37 & \\
\hline 6. & Magnesium oxide, $\mathrm{MgO}$ & $\%$ & 1.65 & \\
\hline 7. & Sodium oxide, $\mathrm{Na} 2 \mathrm{O}$ & $\%$ & 0.65 & \\
\hline 8. & Potassium oxide, $\mathrm{K} 2 \mathrm{O}$ & $\%$ & 0.56 & \\
\hline 9. & Titanium dioxide, $\mathrm{TiO} 2$ & $\%$ & 0 & \\
\hline 10. & $\mathrm{pH}$ & - & 8.5 & Visual \\
\hline
\end{tabular}

Table 3. Diatoms - technical specifications

Authorized tests I.S.C. - laboratory group 1, authorization no.2613 / 04.10 .2012

\subsubsection{Method of research-development of the experimental device}

For the development and application of the used research methods, there were mainly took into account the objectives pursued both in the laboratory experiments (Zeolite, Dolomite and Diatomite products in the final solution formation, as well as the concentration of the working solution), but also for the final tests on the library collections in the deposits.

Table 4 highlights the details for the elaboration of the experimental apparatus and the used research methods, as follows: objective presentation; period - experimental years; the location where the experiments, determinations and analyzes were performed; the contribution of the human factor - the research team; presentation of the variants, sub-variants and repetitions of the experimental apparatus in the laboratory, as well as the interventions regarding the use of the researched method, in the practice of preserving library collections at the library of „Gheorghe Asachi” Technical University, Iași.

1. OBJECTIVE. Research on the use of the micronised product D.Z.D. (1:1:1) for the treatments on the deacidification of info-document collections from libraries, archives and museums in laboratory and storage conditions;

2. PERIOD: 2016-2017;

3. LOCATION: Conservation-research laboratory within „, Gheorghe Şincai” Bihor County Library, Oradea;

4. PARTICIPATION: Dr. Vasile. A. DEAC - ,, Gh. Şincai” Bihor County Library, Oradea;

PhD stud. Ionela BURZ - Library of the University of Oradea

Librarian Mariana IANUȘ - Library of „, Gh. Asachi” Technical University, Iaşi

5. RESEARCH VARIANT: Use of D.Z.D. to carry out laboratory preservation treatments of FÁKLYA Newsprint Collection;

5.1. RESEARCH SUB-VARIANTS - FÁKLYA collection; years of appearance

- sub-variant SV1: 1979;

- sub-variant SV2: 1980;

- sub-variant SV3: 1981.

5.2. NUMBER OF REPETITIONS - the terms of the studied years

- Repetition 1: 1st term;

- Repetition 2: 2nd term;

- Repetition 3: 3rd term;

- Repetition 4: 4th term.

6. VARIANT OF USE IN THE PRESERVATION OF LIBRARY COLLECTIONS: The use of D.Z.D (1: 1: 1) in the practice of preserving collections at the Library of "Gheorghe Asachi" Technical University, Iași

Table 4. Elaborated and applied research apparatus 
Researches on the Use of Micronized Product D.Z.D. (1: 1:1)

in Laboratory and Deposit Conditions for the Deacidification Treatments

of the Info-Documentary Collections from Libraries, Archives and Museums

\section{Scientific results}

In this section, the results obtained through the implementation of the experimental apparatus elaborated and applied both in laboratory and, by professional extension, in the practice of carrying out the treatments for the preservation of library collections, are presented in detail.

\subsection{Considerations about the sources and effects of acidity of info-documentary collections in libraries, museums and archives}

Paper acidity (acidification): harmful factor expressed by the concentration of hydrogen ions in the paper mass that contributes to its degradation by turning to yellow or increased fragility; acidity is the main cause of paper damage (Deac, 2008). The mostly wide-spread sources of acidity are:

- acidity induced by some substances having an acidic chemical structure (rosin and alum, substances used in paper manufacturing;

- from the carboxyl groups produced either for paper bleaching (in the initial preparation of paper) or by the natural degradation of cellulose, caused to a great extent by the presence of heavy metals (iron and copper) in the material structure of the paper;

- from the aluminium sulphate used for the gluing with rosin and alum of papers manufactured after 1807;

- the presence of poor quality lignin and always in the newspaper paper, which break up in compounds that have a strong affinity for sulphur dioxide molecules;

- from the sulphur dioxide found in library locations, which is chemically converted into sulphuric acid in situ;

- a source of paper acidity is represented for a long time (1400-1850)by ferro-gallic inks, because from these inks prepared from ferrous sulphate, nut gall and Arabic gum, sulphuric acid is produced which is corrosive, causing paper punching in some serious situations;

- acids are formed in the paper by oxidation, as a consequence of natural aging, cellulose oxidation leads to the formation of carbon and carboxyl, which accumulate in the internal acidity that can be hardly removed by neutralization treatments;

- other oxidizing agent is the ozone, the acids may be formed by the absorption of acidic compounds from the air: sulphur dioxide, nitrogen monoxide, nitrogen dioxide, carbon dioxide;

- the occurrence and development of the paper acidity is directly proportional to the increase dynamics of the relative humidity's percentage values, especially when it is above $70 \%$;

- the accumulation of paper acidity and the deterioration of cellulose through oxidation and hydrolysis reactions is all the more dynamic (faster) the higher the temperatures in the library locations;

- light is the direct physical factor involved in the photo-chemical processes of paper damage, as long as paper-based info-documentary collections are exposed to light even for short periods of time;

- the aging process (chemical degradation) of paper is greatly influenced by light due to metal ions, which act efficiently as photosensitizers for cellulose (iron oxide, zinc oxide, silver oxide, copper oxide), which means that under the influence of light radiation (the ions react efficiently in the presence of radiation with R-wavelengths less than 340 nanometers); these ions catalyze the cellulose decomposition reactions, which greatly intensify under the influence of the paper's moisture;

- the influence of biological factors (cellulolytic fungi and bacteria, papyrophages, xylophage insects, rodents) on the chemical degradation of info-documentary collections in libraries, museums and archives is known and verified in the practice of conserving info-documentary collections, because the biological agents produce organic acids (citric acid, oxalic acid), 
Researches on the Use of Micronized Product D.Z.D. (1: 1: 1)

in Laboratory and Deposit Conditions for the Deacidification Treatments

of the Info-Documentary Collections from Libraries, Archives and Museums

enzymes or oxidizing agents that are catalysts of paper decomposition, as a result of the feeding metabolism;

- frequency of internal pollutants encountered in libraries, museums and/or archives: organic acids released into the rehabilitated and re-hygienized environments and deposits; Volatile Organic Acids released by the hardwood cabinets and raw wood boxes insufficiently worked and finished; sulphur and sulphur dioxide released by the rubber bands and gaskets used; the sulphur coming from Scotch-like adhesive tapes; nitrogen oxides released by the photographic negatives that have the cellulose nitrate as support; various harmful substances released by adhesives and fillers used in the manufacture of plywood and particleboards.

The main diagnosing symptoms of chemical degradation produced by the acids accumulated in the paper material structures are:

- the presence of incipient or developed yellow areas on the contact surface of the paper;

- the appearance of foxing points;

- oxidation and hydrolysis reactions on the paper;

- cellulose deterioration;

- photo-chemical reactions produced by the intensity and quality of the artificial and/or natural light source;

- cellulose damage by dislodging molecular bonds;

- paper aging;

- paper damage by changing the color of the material to brown (turning color), near the written area;

- paper turning fragile and information loss;

- appearance of paper oxidation points (black points of different sizes and shapes);

- chemical degradation of information due to the inks containing iron, copper and zinc: chemical agents affect the physico-mechanical resistance of paper; fiber size; fiber resistance; the interfibrilar surface of the fiber, etc .;

- acids affect the optical properties of the paper: colour, brilliance, opacity;

- acids affect paper stability, durability and permanence of the material.

Analyzing the incidence of factors (chemical agents) in the installation and development of infodocuments' degradation in libraries, museums and archives, depending on the result of the action of favourable (activating factors) and unfavourable factors (inhibiting blocking factors), a managerial intervention strategy is presented in monitoring and blocking the activation factors (agents) of acids accumulated in the interfibrillar structure of cellulose:

- use of air conditioning equipment in library, museum and archive deposits;

- use of local air conditioning equipment;

- avoiding the entrance of external pollutants into libraries, museums and archives

- avoiding the formation of internal pollutants' sources;

- use of high quality paper - permanent paper;

- monitoring the evolution of the acidity in the case of info-documentary collections by conducting $\mathrm{pH}$ determinations (readings);

- carrying out treatments to neutralize the acidity of documents;

- carrying out prevention-eradication treatments of the biological agents from collections and locations;

- avoidance of photo-chemical degradation: choice of lighting sources; careful exposure of sensitive info-documentary collections. 
Researches on the Use of Micronized Product D.Z.D. (1: 1:1)

in Laboratory and Deposit Conditions for the Deacidification Treatments

of the Info-Documentary Collections from Libraries, Archives and Museums

3.2 Determination of the $\mathrm{pH}$ of the paper from liquid solutions - elaboration of the working methodology regarding the use of Hanna pH-meter

The conservation laboratory from „Gheorghe Şincai” County Library, Bihor, Oradea, uses a pHmeter of Checker - Hanna production with electronic display (photo 1) to determine the $\mathrm{pH}$ of the paper in liquid samples.

The first step is to remove the $\mathrm{pH}$-meter protection helmet and connect the electrode to the measuring device. Then the electrode rod is inserted into the liquid sample (distilled water with $\mathrm{pH}$ 7 , mixed with small pieces of paper) prepared in a laboratory tube. The contents of the test tube is slightly shaken. The electronic display is turned on and there are some moments of waiting for the display to stabilize, after which the indicated $\mathrm{pH}$ is read on the screen. If another analysis is desired, it is necessary to wash (rinse) the electrode in distilled water to minimize chemical contamination.

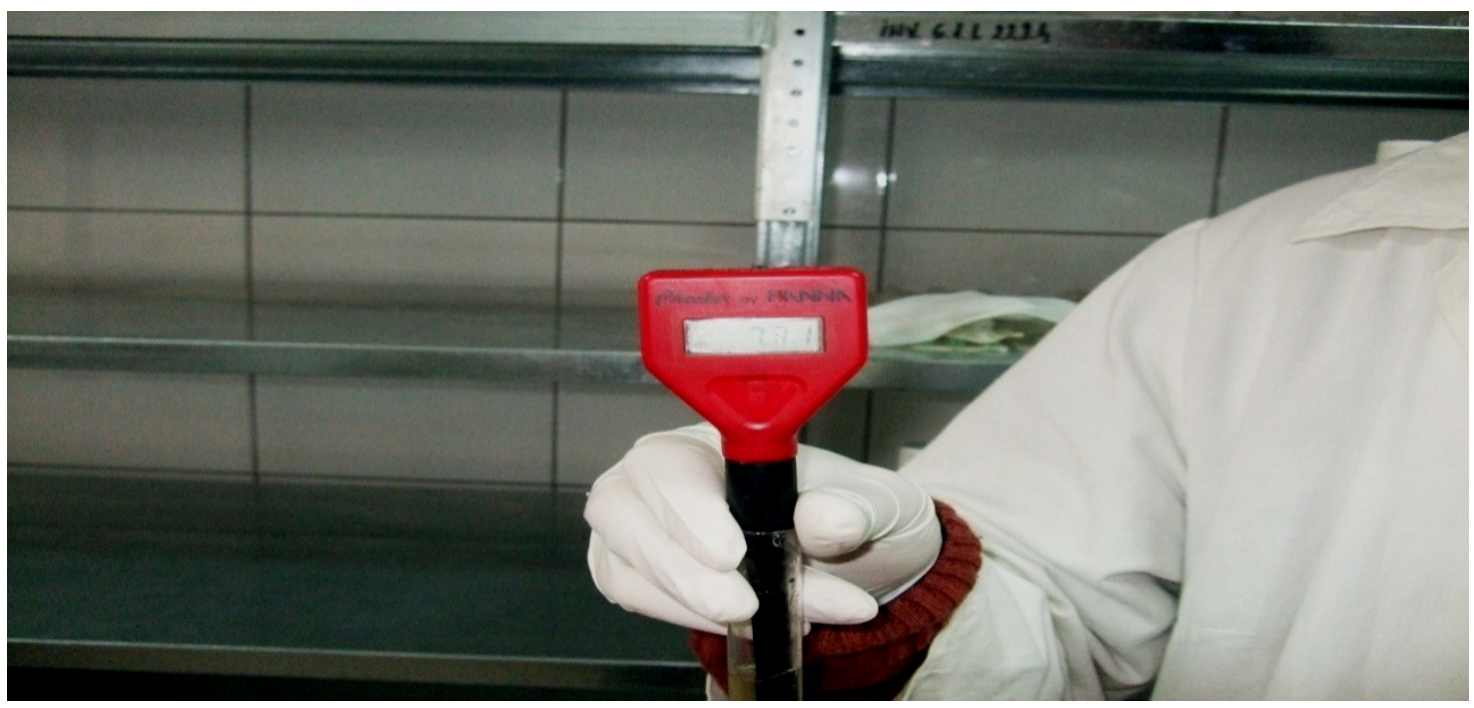

Photo 1. Checker-type pH-meter, Hanna production, with electronic display

\subsection{Determination of paper's $\mathrm{pH}$ by surface determinations}

Surface readings can provide useful information on the dynamics of acidity evolution in valuable info-documentary collections, although some problems can arise regarding the readings' value depending on the morphological (physical, mechanical and chemical) structure of the paper. Surface readings are performed with $\mathrm{pH}$ meters with electrodes that are technically adapted to operate in liquid media. This method, widely spread in surface readings on valuable documents, consists in placing the electrodes in contact with a drop of distilled or deionized water on the surface of the paper. Thus, a mini-solution, a mini-aqueous medium is prepared in which the electrodes act by direct contact.

Disadvantages of surface readings with special pH-meters:

- In some cases there may be encountered some problems with paper surfaces, being either very absorbent or non-absorbent. The absorbent papers will take up so much water that the electrodewater contact (solution) is always interrupted, with no stable $\mathrm{pH}$ that can be recorded. Adding more water to maintain the contact, large water spots may result that are difficult to remove, and the extract can be diluted so that the reading is erroneous. 
Researches on the Use of Micronized Product D.Z.D. (1: 1:1)

in Laboratory and Deposit Conditions for the Deacidification Treatments

of the Info-Documentary Collections from Libraries, Archives and Museums

- Repeated movement of electrodes for a direct contact with the surface of the paper causes the electrodes to be removed from the aqueous medium in which they are intended to function, and the readings carry deviations that sometimes are significant.

- In the case of papers that have a highly glued surface, they will not readily absorb water. Since water is not removed by paper absorption, a good electrode-water contact is maintained, which results in stable readings. But this reading may simply represent the $\mathrm{pH}$ of the bi-distilled water; in this case, the chemical process does not reflect the true value of the paper's acidity excessive absorption produces slight staining with excess dionised water, and insufficient absorption gives erroneous $\mathrm{pH}$ values.

Advantages of surface readings with special pH-meters:

- Surface readings, through direct contact with the paper, with special $\mathrm{pH}$ meters, are the only techniques agreed upon to monitor the acidity of valuable info-documentary collections.

- Surface readings, through direct contact with the paper, can provide useful information on the evolution of acidity expressed by $\mathrm{pH}$ units.

- In the case of modern, last generation $\mathrm{pH}$ meters, the hydrogen ion concentration meter can be connected to a PC (computer) to capture data online.

- $\mathrm{pH} / \mathrm{mV}$ or temperature recordings $(0 \mathrm{C} / 0 \mathrm{~F})$ can be saved in document files and the data can be used in: operational analyzes; conducting evolution statistics of thr $\mathrm{pH}$ and temperature readings; displaying multiple documents on the monitor; customized features; plotting histograms (charts) of $\mathrm{pH}$ or temperature.

- If all installation, use and storage operations (after reading) are met, the special $\mathrm{pH}$ meters used for surface readings (through direct contact with the paper) provide readings that reflect the true acidity value of the paper.

- Calibration possibilities of the portable station with the contact electrode in standard $\mathrm{pH}$ solution $(\mathrm{pH} 4, \mathrm{pH} 7, \mathrm{pH} \mathrm{10)}$, by accessing the controls in an integral electronic system, eliminates measurement errors up to the standard value recognized by the authorized institutions in the standardization of paper acidity measurement operations.

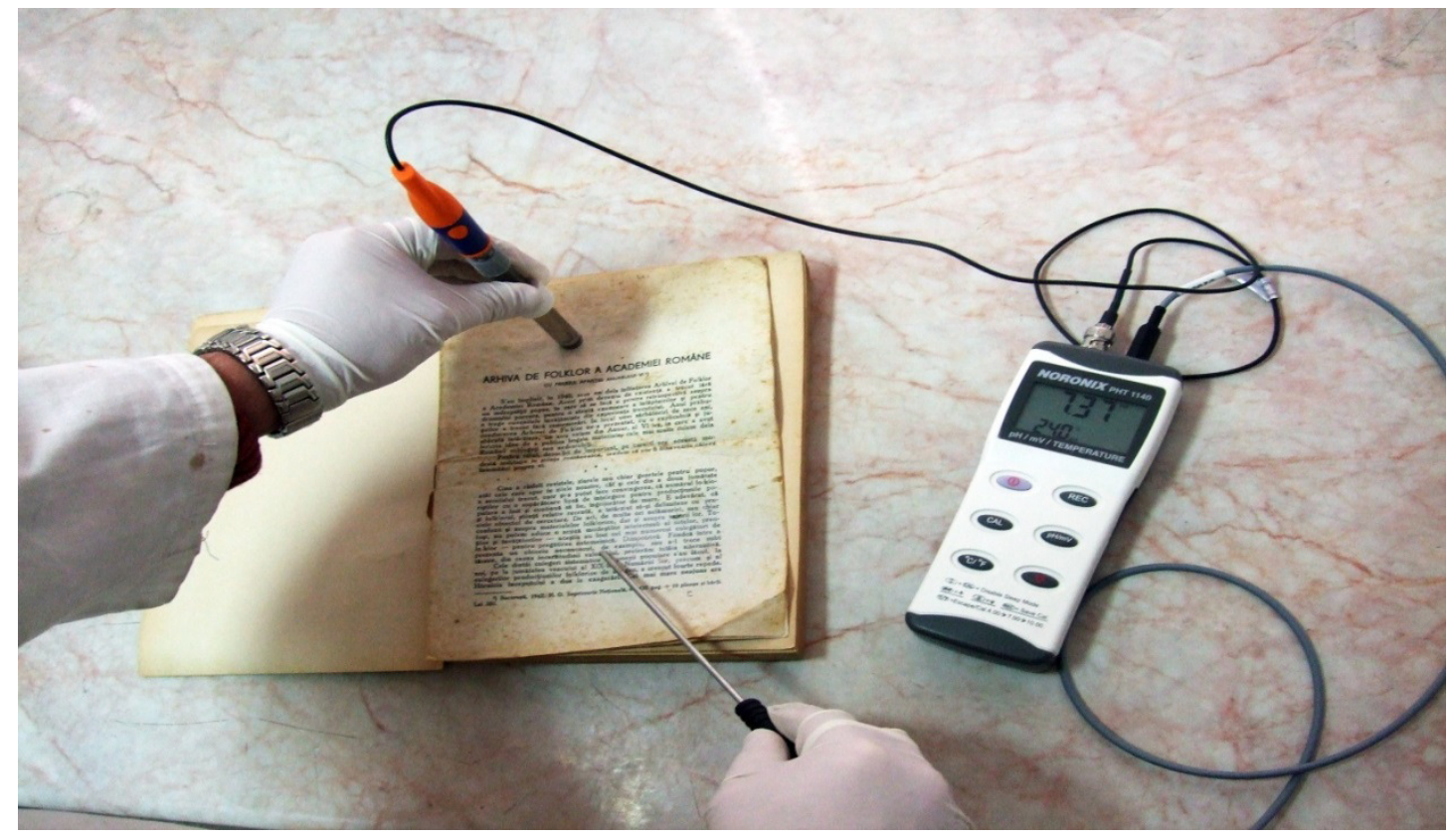

Photo 2. Noronix PHT 1140 pH meter prepared for performing the acidity readings 
Researches on the Use of Micronized Product D.Z.D. (1: 1:1)

in Laboratory and Deposit Conditions for the Deacidification Treatments

of the Info-Documentary Collections from Libraries, Archives and Museums

The conservation laboratory from „Gheorghe Şincai” County Library, Bihor, Oradea, uses a last generation $\mathrm{pH}$ meter for surface readings, Noronix PHT 1140 type, foreseen with: portable station with contact electrode for measuring acidity; electrode sensor for temperature determination (in ${ }^{0} \mathrm{C} /{ }^{0} \mathrm{~F}$ ); RS 232 software for online data storage and processing (see Photo 2).

\subsection{Researches on the evolution of $\mathrm{pH}$ values on the research variants and repetitions presented in the research apparatus; used product: Zeolit+Dolomite+Diatomite $2 \%$}

Regarding the reaction medium used to perform the deacidification treatments of the used document collections, the following pre- and post-treatment aspects were highlighted as follows:

- performing treatments on the deacidification of Fáklya newsprint collection, during the period 1979-1981, terms 1-4, represented a necessity to save the edited newsprint in the Hungarian language, which was in a state of precarious preservation due to inadequate storage conditions;

- the working solution developed and used to perform acid correction treatments was made up of the combined zeolite product - 70 gr. - to control the microbial flora at library locations + Dolomite - $70 \mathrm{gr}$. for the correction of the acidity of the paper, the hardening of the paper and the fixing of the text. + Diatomite - 70 gr. - for the protection of the paper structures from the attack of the paper insects;

- the combined product, which is the research variant, was dissolved in a 10 liter distilled water tank having a $\mathrm{pH}$ of 7.4 ;

- deionized water has not been used because it is acidic, being devoid of not only the harmful elements, but also of those necessary for the preservation of the newsprint documents;

- the reaction environment represented the final solution having a $\mathrm{pH}$ of 8.6 for wet interventions, by brushing the pages of each document on all components (double-sided);

- the documents thus treated were fastened with special clamps on a restoration string located at a height of about $2 \mathrm{~m}$ in the space of the conservation lab;

- the following aeration devices have been used for drying the treated documents: ICAF 2-M model special device for the aeration of the conservation and restoration laboratories; two space aeration devices;

- acidity determinations as well as the study of the dynamics and statistical processing of readings (about 500) by tracing the $\mathrm{pH}$ values, before and after the treatments, were performed with Noronix PHT 1140 pH meter;

- the graphs on dynamics and statistical processing of $\mathrm{pH}$ readings were highlighted in the annexes of the material.

As regards the achieved scientific results (see Tables 5 and 6), the following aspects have been highlighted:

- in Table 5, the evolution of $\mathrm{pH}$ values, on the research variants and the repetitions, was analyzed by using Zeolite + Dolomite $+2 \%$ Diatomite product in a reaction environment made up of distilled water with a $\mathrm{pH}$ of 7.4 ;

- the final value of the $\mathrm{pH}$ for the intervention solution was 8.6;

- the performed treatments fully justified the composition and effectiveness of the complex product D.Z.D. (Dolomite-Zeolite-Diatomite) in the preservation of documents by: neutralizing the acidity of the information carriers and bringing the $\mathrm{pH}$ to neutral values (6.9-7.2); eliminating the risk of degradation of information-bearing paper through preventive decontamination interventions with aspergillus-penicillin pathogens, and the removal of the 
Researches on the Use of Micronized Product D.Z.D. (1: 1:1)

in Laboratory and Deposit Conditions for the Deacidification Treatments

of the Info-Documentary Collections from Libraries, Archives and Museums

infestation conditions of Fáklya Newsprint Collection (1979-1981, 1-4 terms) with papyrophage insects, due to the fact that diatomite possesses a small amount of pyrethine (natural insecticide) that irritates the nervous system of insects from library environments (museum, archive); the observations made on a special magnifying glass on the treated documents reveal a restoration of the paper by neutralizing and washing the acidity points; the post-treatment status of documents by restoring chemical and mechanical indices, offer a new chance, if appropriate conservation and consultation measures are provided.

Regarding the definition and calculation of the neutralization index as well as the establishment but also the impact of the values as significance of INAD (Table 6), the researches carried out in the laboratory from Oradea, as well as the processing of the obtained data, represent an authentic scientific approach that offers a synthesis analyzed through the documents' acidity neutralizing indices and valorized by their statistical significance, as follows:

- the statistical model elaborated and applied in the deacidification treatments of the collections from „Gheorghe Şincai” County Library Bihor, Oradea, as well as from "Gheorghe Asachi” Technical University Library, is a useful working tool for finding and quantifying the usefulness and efficiency of the applied treatments;

- Index of Documents' Acidity Neutralization (IDAN) (\%) represents the percentage of neutralization of free acidity in the newsprint paper, based on which the effectiveness of the performed treatment, the existing alkaline reserve and its equivalence with the incorporation of $2 \% \mathrm{CaCO} 3$ or $\mathrm{MgCO} 3$, the homogeneity of $\mathrm{pH}$ distribution and the alkaline reserve of paper, the stage of acid neutralization inside the paper, paper $\mathrm{pH}$ (minimum, maximum and average value) can be determined;

- the interpretation of the results regarding the acidity neutralisation index of the documents treated on the research variants was performed by using the significance levels (Table 6);

- examples to use Table 6: for Fáklya variant 1979, first term, the average value of the $\mathrm{pH}$ for the untreated control document was 4.7; for the treated document the $\mathrm{pH}$ was 6.9; IDAN determination was made by dividing the treated $\mathrm{pH}$ value to the untreated $\mathrm{pH}$, the result is multiplied by 100 (46.8-acidity neutralization index); the presented calculation mode is respected for all the work variants highlighted in the experimental apparatus;

- the analysis of Table 6 revealed IDAN values with a distinctly significant degree in the case of the nine terms, and 3 terms had a very significant IDAN;

- by analyzing the synthesis on the total experimental device (research variants and sub-variants Table 6), the following values were obtained:

- average $\mathrm{pH}$ value for the untreated documents-control variant: 4.6;

- average $\mathrm{pH}$ value for treated documents: 7.05 ;

- distinctly significant average value of IDAN (\%) for treated documents: $66.92 \%$. 
Researches on the Use of Micronized Product D.Z.D. (1: 1:1)

in Laboratory and Deposit Conditions for the Deacidification Treatments

\begin{tabular}{|c|c|c|c|c|c|c|c|c|c|c|c|c|c|}
\hline \multirow{3}{*}{$\begin{array}{c}\text { Crt. } \\
\text { no. }\end{array}$} & \multirow{3}{*}{$\begin{array}{l}\text { Document title } \\
\text { and year of } \\
\text { appearance }\end{array}$} & \multicolumn{6}{|c|}{ Term I } & \multicolumn{6}{|c|}{ Term II } \\
\hline & & \multicolumn{3}{|c|}{ untreated $\mathrm{V} 1$} & \multicolumn{3}{|c|}{ treated V2 } & \multicolumn{3}{|c|}{ untreated V1 } & \multicolumn{3}{|c|}{ treated $\mathrm{V} 2$} \\
\hline & & $\begin{array}{l}\min \\
\text { (m) }\end{array}$ & $\begin{array}{l}\text { Max } \\
\text { (M) }\end{array}$ & $\begin{array}{l}\text { Aver. } \\
\text { (md) }\end{array}$ & $\begin{array}{l}\min \\
\text { (m) }\end{array}$ & $\begin{array}{l}\text { Max } \\
\text { (M) }\end{array}$ & $\begin{array}{l}\text { Aver. } \\
\text { (md) }\end{array}$ & $\begin{array}{l}\min \\
\text { (m) }\end{array}$ & $\begin{array}{l}\text { Max } \\
\text { (M) }\end{array}$ & $\begin{array}{l}\text { Aver. } \\
\text { (md) }\end{array}$ & $\begin{array}{l}\min \\
(\mathrm{m})\end{array}$ & $\begin{array}{l}\text { Max } \\
\text { (M) }\end{array}$ & $\begin{array}{l}\text { Aver. } \\
\text { (md) }\end{array}$ \\
\hline 1. & Fáklya 1979 & 4.5 & 5.1 & 4.7 & 6.4 & 7.4 & 6.9 & 4.2 & 5.0 & 4.4 & 6.7 & 7.2 & 7.0 \\
\hline 2. & Fáklya 1980 & 4.1 & 4.7 & 4.2 & 6.5 & 7.3 & 7.0 & 3.7 & 4.0 & 3.7 & 6.9 & 7.4 & 7.1 \\
\hline 3. & Fáklya 1981 & 3.9 & 4.8 & 4.2 & 6.9 & 7.4 & 7.0 & 4.5 & 4.7 & 4.6 & 7.3 & 7.1 & 7.2 \\
\hline \multirow{3}{*}{$\begin{array}{c}\text { Crt. } \\
\text { no. }\end{array}$} & \multirow{3}{*}{$\begin{array}{l}\text { Document title } \\
\text { and year of } \\
\text { appearance }\end{array}$} & \multicolumn{6}{|c|}{ Term III } & \multicolumn{6}{|c|}{ Term IV } \\
\hline & & \multicolumn{3}{|c|}{ untreated V1 } & \multicolumn{3}{|c|}{ treated $\mathrm{V} 2$} & \multicolumn{3}{|c|}{ untreated V1 } & \multicolumn{3}{|c|}{ treated V2 } \\
\hline & & $\begin{array}{l}\min _{(\mathrm{m})} \\
\end{array}$ & $\begin{array}{l}\text { Max } \\
\text { (M) }\end{array}$ & $\begin{array}{l}\text { Aver. } \\
\text { (md) }\end{array}$ & $\begin{array}{l}\min \\
\text { (m) }\end{array}$ & $\begin{array}{l}\text { Max } \\
\text { (M) }\end{array}$ & $\begin{array}{l}\text { Aver. } \\
\text { (md) }\end{array}$ & $\begin{array}{l}\min _{(\mathrm{m})} \\
\text { (m) }\end{array}$ & $\begin{array}{c}\text { Max } \\
\text { (M) }\end{array}$ & $\begin{array}{l}\text { Aver. } \\
\text { (md) }\end{array}$ & $\begin{array}{l}\min \\
(\mathrm{m})\end{array}$ & $\begin{array}{c}\text { Max } \\
\text { (M) }\end{array}$ & $\begin{array}{l}\text { Aver. } \\
\text { (md) }\end{array}$ \\
\hline 1. & Fáklya & 4.2 & 4.6 & 4.4 & 6.7 & 7.0 & 6.9 & 4.5 & 5.0 & 4.7 & 5.9 & 7.2 & 6.9 \\
\hline 2. & Fáklya 1980 & 3.6 & 4.3 & 3.8 & 6.9 & 7.4 & 7.1 & 3.2 & 4.6 & 3.6 & 6.9 & 7.4 & 7.1 \\
\hline 3. & Fáklya 1981 & 4.5 & 4.7 & 4.6 & 7.3 & 7.1 & 7.2 & 4.5 & 4.8 & 4.2 & 7.1 & 7.3 & 7.2 \\
\hline
\end{tabular}

Table 5. Evolution of $p H$ values on the research variants and repetitions; used product: Zeolite + Dolomite +Diatomite 2\% (Oradea, 2017)

Technical data: equal parity combination between Zeolite $70 \mathrm{gr}+$ Dolomite $70 \mathrm{gr}+$ Diatomite $70 \mathrm{gr}$ $2 \%$ concentration; volume of used solution 10 liters; the reaction medium consisted of distilled water with a $\mathrm{pH}$ of 7.4 ; the final solution for brushing the double-sided document but also its washing if necessary, had a $\mathrm{pH}$ of 8.6; gripping display.

\begin{tabular}{|c|c|c|c|c|c|c|}
\hline \multirow{2}{*}{$\begin{array}{c}\text { Crt. } \\
\text { no. } \\
\\
1 .\end{array}$} & \multicolumn{2}{|c|}{ Specification } & \multirow{2}{*}{$\begin{array}{c}\text { pH average } \\
\text { value for } \\
\text { control } \\
\text { document } \\
\text { (untreated) }\end{array}$} & \multirow{2}{*}{ 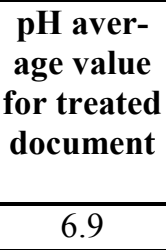 } & \multirow{2}{*}{$\begin{array}{c}\begin{array}{c}\text { Index of } \\
\text { document } \\
\text { acidity } \\
\text { neutralization } \\
\text { (IDAN) (\%) }\end{array} \\
46.8^{* *}\end{array}$} & \multirow{2}{*}{$\begin{array}{c}\begin{array}{c}\text { IDAN Significance (significance } \\
\text { levels) }\end{array} \\
\text { Distinctly significant value }\end{array}$} \\
\hline & Fáklya & Term I & & & & \\
\hline & 1979 & Term II & 4.4 & 7.0 & $59.1 * *$ & Distinctly significant value \\
\hline & & Term III & 4.4 & 6.9 & $56.8^{* *}$ & Distinctly significant value \\
\hline & & Term IV & 4.7 & 6.9 & $46.8^{* *}$ & Distinctly significant value \\
\hline \multirow[t]{4}{*}{2.} & \multirow{4}{*}{$\begin{array}{l}\text { Fáklya } \\
1980\end{array}$} & Term I & 4.2 & 7.0 & $66.7 * *$ & Distinctly significant value \\
\hline & & Term II & 3.7 & 7.1 & $91.8^{* * *}$ & Very significant value \\
\hline & & Term III & 3.8 & 7.1 & $86.8 * * *$ & Very significant value \\
\hline & & Term IV & 3.6 & 7.1 & $97.2 * * *$ & Very significant value \\
\hline \multirow[t]{4}{*}{3.} & \multirow{4}{*}{$\begin{array}{l}\text { Fáklya } \\
1981\end{array}$} & Term I & 4.2 & 7.0 & $66.7^{* *}$ & Distinctly significant value \\
\hline & & Term II & 4.6 & 7.2 & $56.5^{* *}$ & Distinctly significant value \\
\hline & & Term III & 4.6 & 7.2 & $56.5^{* *}$ & Distinctly significant value \\
\hline & & Term IV & 4.2 & 7.2 & $71.4 * * *$ & Very significant value \\
\hline verag & values - & 19nifıcance & 4.25 & 7.05 & $66.92^{* *}$ & Distinctly significant value \\
\hline
\end{tabular}

Table 6. Calculation of the acidity neutralization index of the treated documents.

\section{Establishment of IDAN significances}

Legend: Interpretation of results by means of IDAN significance levels (index of document acidity neutralization $-\%$ - according to the statistical weight of the $\mathrm{pH}$ value)

0... insignificant increase: $0-19 \%$

* significant increase: $20-39 \%$

** distinctly significant increase: $40-69 \%$

*** very significant increase: $70-100 \%$ 
Researches on the Use of Micronized Product D.Z.D. (1: 1:1)

in Laboratory and Deposit Conditions for the Deacidification Treatments

of the Info-Documentary Collections from Libraries, Archives and Museums

\section{Conclusions and Recommendations}

Composite material combines in a single micronized product (3-10 microns) some qualities that are not naturally and individually highlighted.

The micronized Zeolite product is useful for the library collections kept in insalubrious locations to decontaminate library collections, modules and locations.

Micronized Dolomite neutralizes the acids inside the paper, provides an alkaline reserve necessary as a buffer system against acidity sources, contributes to the elaboration and application of mass deacidification processes of library info-documentary collections from libraries, museums and archives.

Diatomite, namely diatomaceous earth can be considered as the natural insecticide which can be used both in complex composite structures for the preservation of collections by the presence of natural pyrethroids that provide these characteristics and separately in solid form (powder).

The usage of this 2\% DZD composite for the deacidification treatments of Fáklya Newsprint Collection (1979-1981 - 1-4 terms) represented a new scientific approach in the Romanian literature and practice, which was effective in terms of low financial effort, but also because of its beneficial effects due to the treatment application: Index of Document Acidity Neutralization (IDAN) showed a distinctly significant average value of $66.92 \%$; the average value of the $\mathrm{pH}$ for the untreated control documents was of $4.25 \%$, and the average value of the $\mathrm{pH}$ for the treated documents was of $7.05 \%$.

By using D.Z.D. composite product (1: 1: 1), the mass deacidification of the books can be performed without dismantling the binding of the books.

Criteria to be followed when performing deacidification treatments of collections by using D.Z.D. micronized product $(1: 1: 1)$ :

- purpose of treatments: neutralization of the paper's free acidity in order to extend the life of the documents;

- the natural product applied does not pose any danger to operators or users;

- neutralization of acids from paper must be complete;

- the $\mathrm{pH}$ should be between 7-8.5 to prevent acid or alkaline hydrolysis of paper and inks;

- D.Z.D. product must remain reversible over time;

- D.Z.D. product as well as laboratory or deposit procedures are compatible with environmental protection standards. 
Researches on the Use of Micronized Product D.Z.D. (1: 1:1)

in Laboratory and Deposit Conditions for the Deacidification Treatments of the Info-Documentary Collections from Libraries, Archives and Museums

\section{ANNEXES}

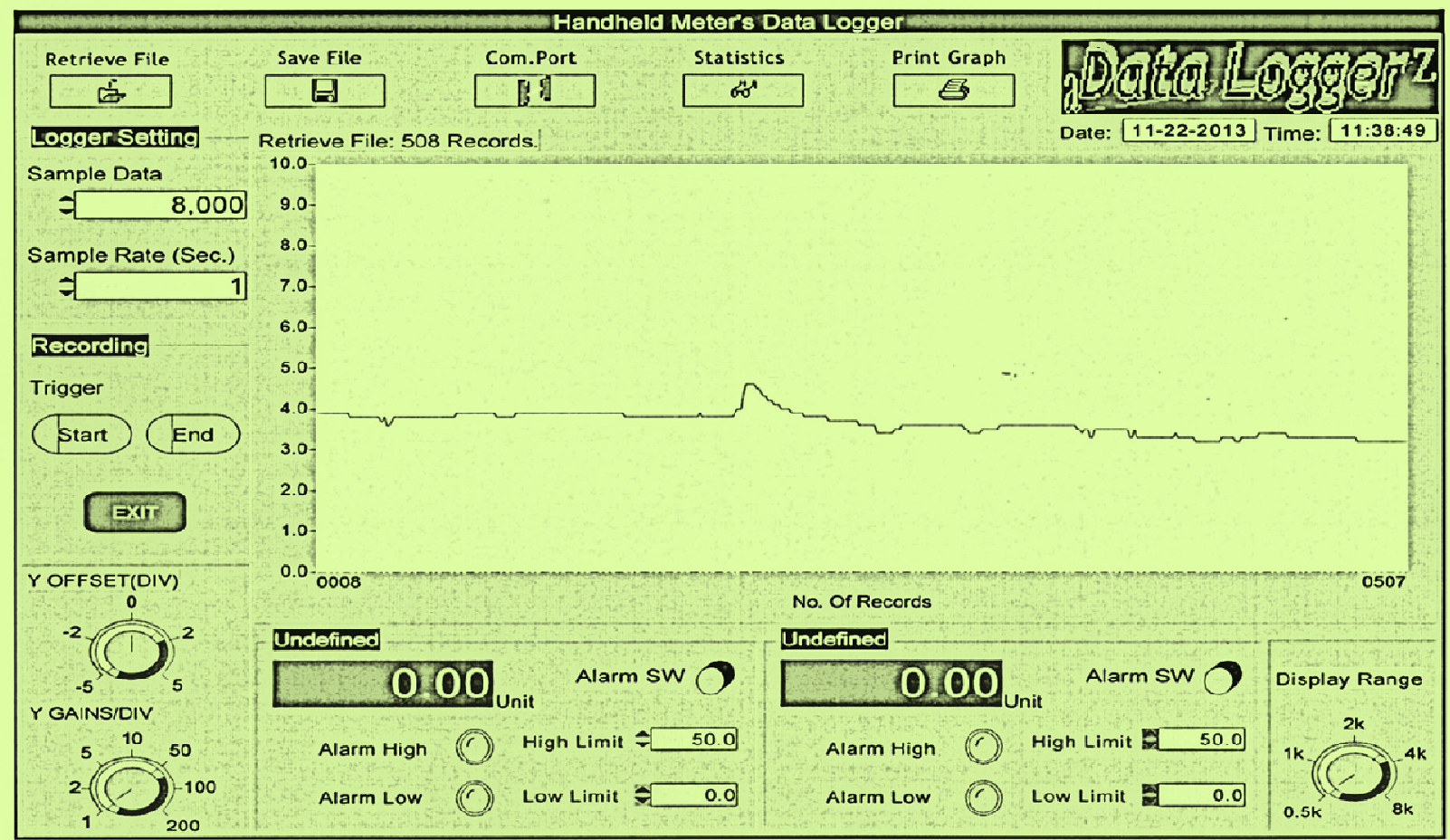

Evolution of the pH on the newsprint documents - graph plotting; ,Gh. Sincai” County Library,

Oradea. Fáklya collection. Year 1980. Term IV. Research control variant V1 (untreated)

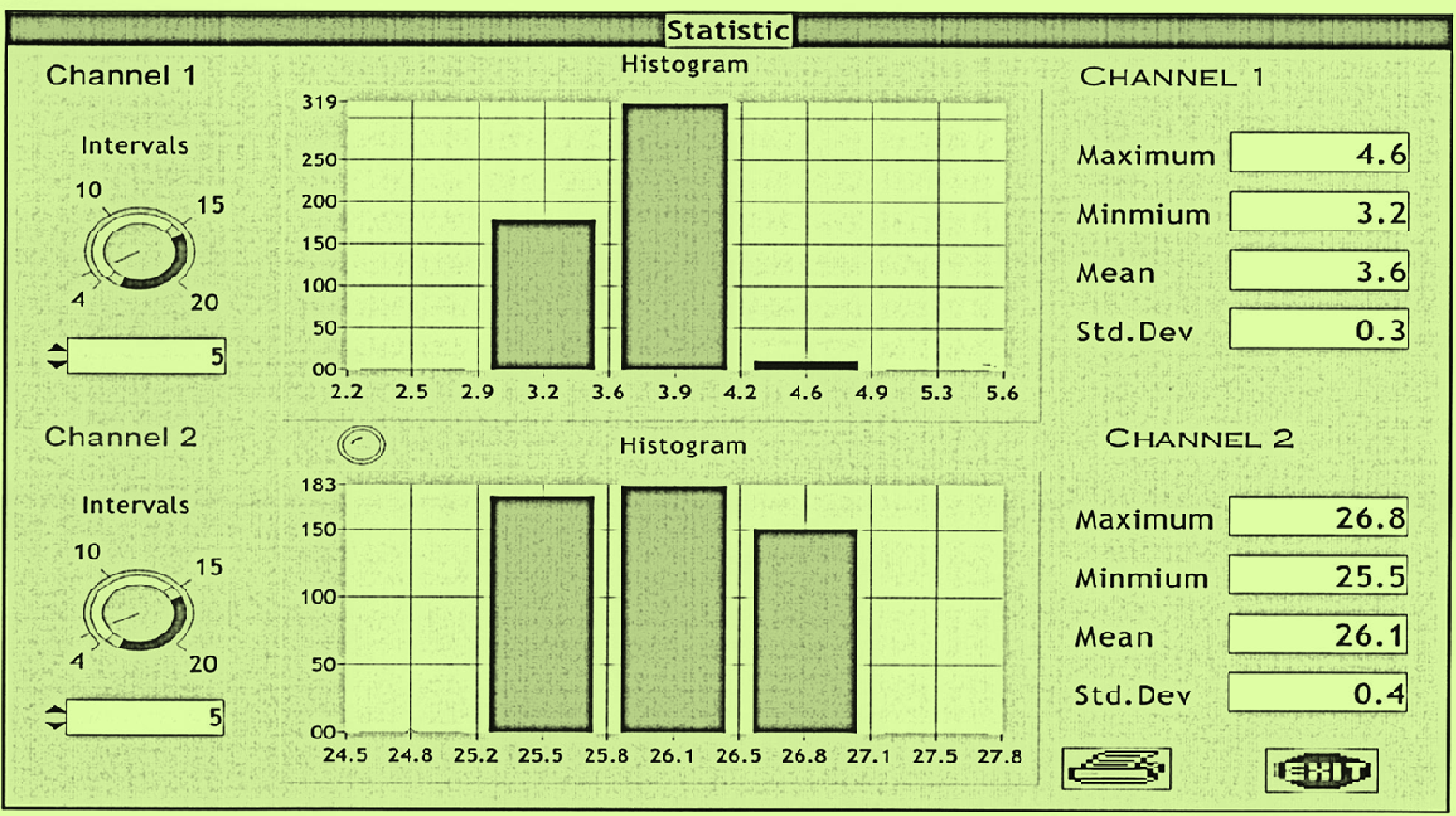

Evolution of the pH on the newsprint documents - performing the statistical calculus;

„, Gh. Şincai” County Library Oradea. Fáklya collection. Year 1980. Term IV.

Research control variant V1 (untreated) 
Researches on the Use of Micronized Product D.Z.D. (1: 1:1)

in Laboratory and Deposit Conditions for the Deacidification Treatments of the Info-Documentary Collections from Libraries, Archives and Museums

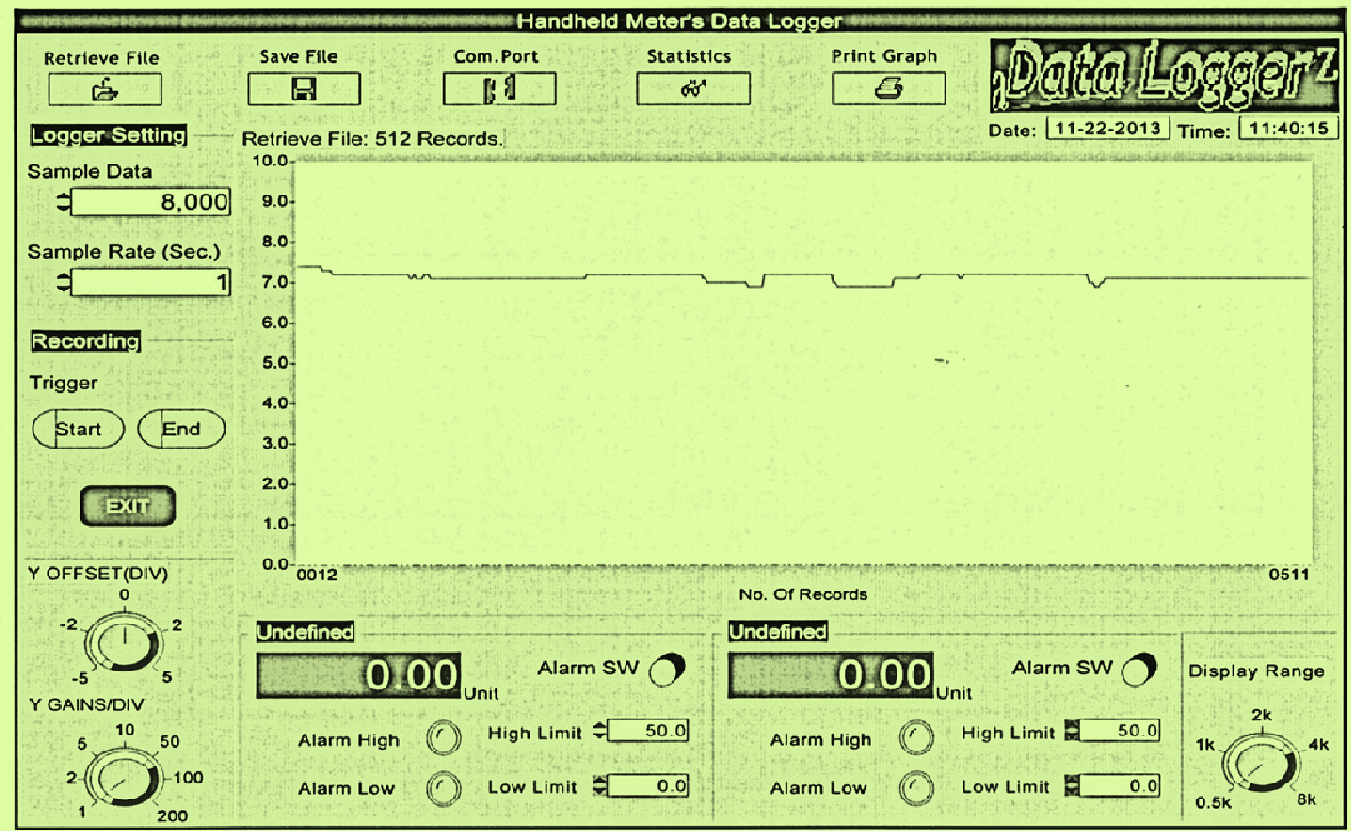

Evolution of the pH on the newsprint documents - graph plotting; „, Gh. Sincai” County Library Oradea. Fáklya collection. Year 1980. Term IV. Research variant V2 (treated)

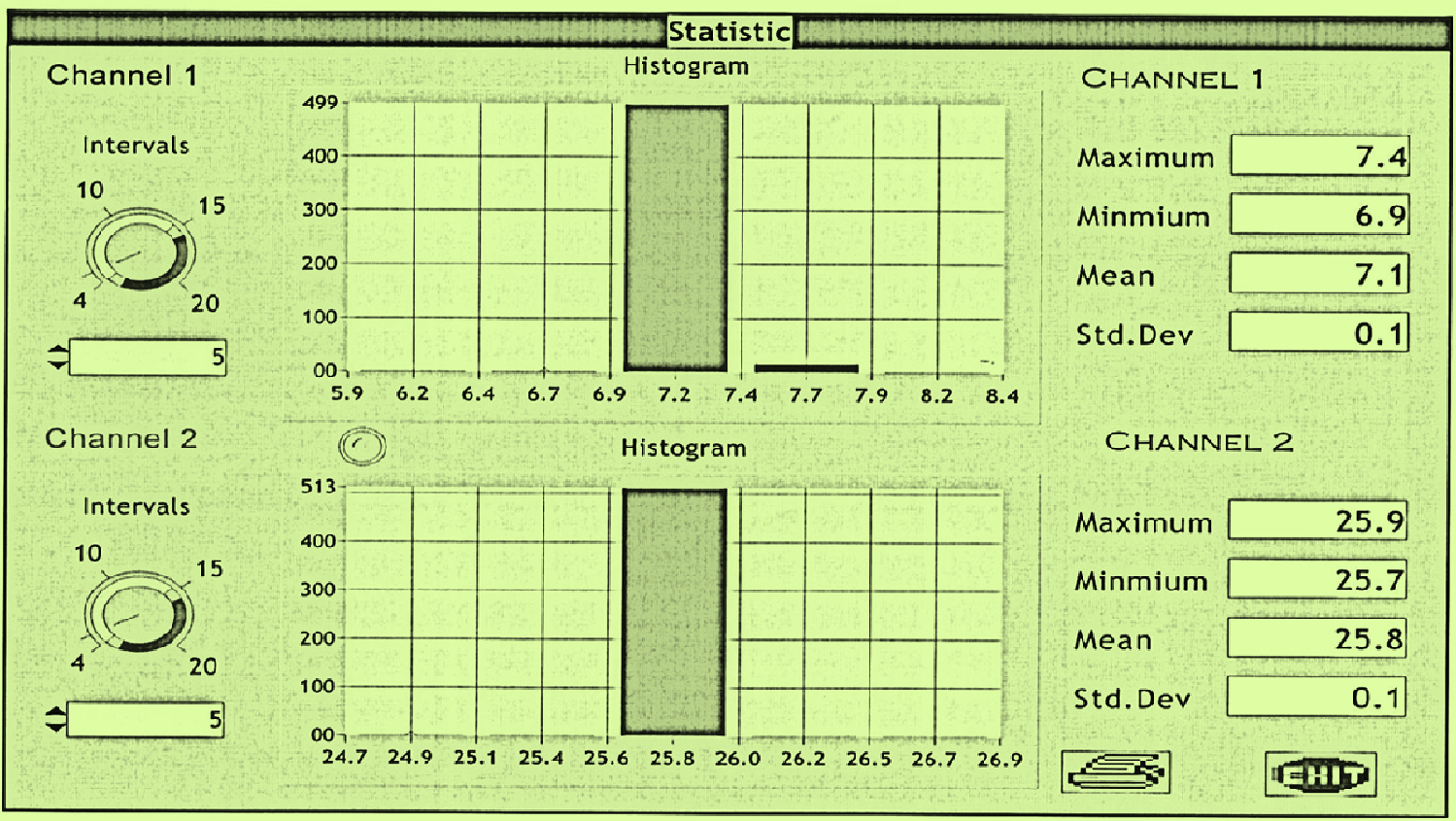

Evolution of the pH on the newsprint documents - performing the statistical calculus; „Gh. Şincai” County Library Oradea. Fáklya collection. year 1980. Term IV. Research variant V2 (treated) 


\section{Notes}

1. Dolomite-Zeolite-Diatomite (1:1:1).

2. Sizes of nano-particles between 1 and 5 microns, used in lab experiments, are considered as being the optimum ones for the usage of the nano-products in the preservation treatments of the info-documentary collections from libraries, museums and archives.

\section{References}

Blanc, F. et al. (2007) Highly Active, Stable, and Selective Well-Defined Silica Supported Mo Imido Olefin Metathesis Catalysts, Journal of the American Chemical Society, 129(5), pp. 10441045, available: https://doi.org/10.1021/ja068249p [accessed 10.08.2017].

Deac, V. (2009) Conservarea colecţiilor infodocumentare din biblioteci, muzee şi arhive. Simptomatologia complexului de degradare [Conservation of infodocumentary collections in libraries, museums and archives. Symptomatology of the degradation complex], Bucureşti: Centrul de Pregătire Profesională în Cultură.

Deac, V. (2017) Investigații privind starea de conservare a colecţiilor infodocumentare. Lucrări practice de laborator. Ghid practic de conservare [Investigations on the state of preservation of infodocumentary collections. Practical laboratory work. Practical Guide to Conservation], [s.1.]: [s.n.].

Heo, J., Hock, A.S. and Gordon, R.G. (2010) Low Temperature Atomic Layer Deposition of Tin Oxide, Chemistry of Materials, 22(17), pp. 4964-4973, available: https://doi.org/10.1021/ $\underline{\mathrm{cm} 1011108}$ [accessed 11.09.2107].

Hock, A. S., Schrock, R. R. and Hoveyda, A. H. (2006) Dipyrrolyl Precursors to Bisalkoxide Molybdenum Olefin Metathesis Catalysts, Journal of the American Chemical Society,128(50), pp. 16373-16375, available: https://doi.org/10.1021/ja0665904 [accessed 10.01.2018].

Hock, A.S. and Schrock, R.R. (2007) Oxidative Reactions of the MoIV Dialkyl Complex [\{(3CF3C6H4NCH2CH2)2NMe\}Mo(CH2SiMe3)2], Chemistry - An Asian Journal, 2(7), pp. 867-874, available: https://doi.org/10.1002/asia.200700093 [accessed 15.09.2017].

Jula, R. (2003) Cercetări privind degradarea colecţiilor la depozitul general de la Biblioteca Judeţeană „Gheorghe Şincai” Bihor [Research on the degradation of collections at the general warehouse at the County Library „Gheorghe Şincai” Bihor], Sănătatea cărţilor, 2(1), pp. 38-40.

Marinescu, S.C. et al. (2008) Syntheses and Structures of Molzbdenum Imido Alkylidene Pyrrolide and Indolide Complexes, Organometallics, 27(24), pp. 6570-6578, available: https:// doi.org/10.1021/om800816q [accessed 9.08.2017].

Mălinaș, C. (2003) Puntea conservării (III) [The bridge of preservation], Sănătatea cărţilor, 2(1), pp. 1-3. 